\title{
ASSOCIATION BETWEEN MATERNAL EDUCATION AND KNOWLEDGE OF COMPLEMENTARY FEEDING IN TEGALREJO, YOGYAKARTA
}

\author{
Dewi Rokhanawati'1,2), Evitriani'1) \\ 1)Study Program in Midwifery, Universitas Aisyiyah Yogyakarta \\ 2)Doctoral Program in Public Health, Universitas Sebelas Maret
}

\begin{abstract}
Background: From 6 months of age infants need breast milk and solid foods to promote health, support growth and enhance development. This is called complementary feeding. It ensures that infants receive all the necessary nutrients, including those that are sometimes missing for many infants (iron, zinc and vitamin A). Introducing foods like meat, eggs and liver in the early stages of complementary feeding is recommended, because these foods are good sources of these nutrients. This study aimed to determine association between maternal education and knowledge of complementary feeding.

Subjects and Method: This was a cross-sectional study conducted in Yogyakarta. A sample of 36 lactating mothers was selected for this study. The dependent variable was knowledge of complementary feeding. The independent variable was the maternal education. The data were collected by questionnaire and analyzed by chi square with odd ratio as the measure of association.

Results: Maternal education was positively associated with knowledge of complementary feeding ( $\mathrm{OR}=3.20$; CI $95 \%=1.91$ to $5.40 ; \mathrm{p}=0.001)$.

Conclusion: Higher maternal education is associated with better knowledge of complementary feeding.

Keywords: maternal education, knowledge, complementary feeding

\section{Correspondence:}

Dewi Rokhanawati. Study Program in Midwifery, Universitas Aisyiyah Yogyakarta/ Doctoral Program in Public Health, Universitas Sebelas Maret, Jl. Ring Road Barat No. 63, Nogotirto, Gamping, Sleman, Yogyakarta 55592.

Email: dewik.2011@gmail.com. Mobile: 081236093816
\end{abstract}

